\title{
Effect of Different Filter Methods on Seawater Quality at a Marine Scallop Hatchery
}

Thorolf Magnesen ${ }^{1 *}$, Anita Jacobsen ${ }^{2}$, and Malebo Hellen Moepi ${ }^{1}$

${ }^{1}$ Department of Biology, University of Bergen, PO Box 7803, N-5020 Bergen, Norway

${ }^{2}$ Institute of Marine Research, PO Box 1870 Nordnes, N-5817 Bergen, Norway

\begin{abstract}
The effect of using two different filtering methods in the main seawater inlet to a scallop (Pecten maximus) hatchery in Norway was tested. Seawater was filtered through active filter media (AFM) and a protein skimmer, or through a drum filter and a protein skimmer. Seawater quality was characterized and tested on algal growth rate, egg development and larval activity. Tests were performed under winter and spring conditions (March, April and May 2009).

Both seawater treatments reduced the dissolved organic carbon concentrations in the inlet seawater. The total bacterial number was stable in both seawater treatments, except for an increase in the drum filter in March. The bacterial community showed seasonal development: Actinobacteria and Alphaproteobacteria dominated in March, while Gammaproteobacteria dominated in April and May. In a cluster analysis, samples from both seawater treatments showed high similarity on similar sampling dates. Vibrio spp. occurred, but was never observed in seawater coming from the skimmer after the drum filter. This sampling point was often clustered as most similar to the incoming seawater.

The fraction of scallop eggs that developed into veliger larvae increased from $10 \%$ to $50 \%$ during the sampling period, and no significant differences were found between the two seawater treatments. The fraction of 8 day old active larvae was lowest in March, in experiments with both undiluted and diluted (1:10, 1:100) seawater from both treatments. No significant difference in activity was found between the treatments, except for undiluted (April) and 100 -fold dilution (April and May) from the drum filter, when the larval activity was significantly higher. The effect of both seawater treatments was tested by growing the diatom Chaetoceros muelleri in small volumes for 4-5 days. Daily growth rates $(\mu)$ varied between 0.75 and 1.15, and were highest in May. No significant difference in cell concentration was found between the treatments. The results showed that the skimmer attached to the drum filter had the best performance overall in reducing dissolved organic carbon and potentially lethal bacteria. These findings have important implications for hatchery seawater management protocols.
\end{abstract}

Keywords: Seawater quality; Seawater treatment; Filter; Protein skimmer; Marine hatchery; Scallop

\section{Introduction}

Pecten maximus, the great scallop, is widely distributed in Norway, and is an aquaculture species with potential and high market values for human consumption [1-4]. The availability of spat is one of the main suppressing factors for aquaculture growth $[5,6]$. In Norway, production relies on spat produced in the hatchery [7-10]. Hatchery production has often been variable due to low larval survival associated with bacteria $[11,12])$. Larval survival has often been seasonal and associated with changes in seawater quality occurring during spring bloom conditions [13]. A number of investigations have shown that the deep seawater masses in the Atlantic Ocean contain large amounts of particulate material, also called marine snow [14-16]. Marine snow may contain the remains of different plankton organisms that have sedimented down from upper seawater masses, such as detritus or diatoms [15]. Investigations of marine snow have also shown that both the density and size of the particles vary greatly throughout the year and between different localities as the particles settle down to the seafloor [14,17].

The aggregation of small particles into larger ones increases the rate of settling down, which in turn affects the distribution of organic and inorganic matter in the seawater masses [17]. Turley (2002) reported on a build-up of marine snow in the North Atlantic during spring and autumn [16]. This organic matter often functions as a substrate for a number of marine bacteria, such as Vibrio spp. and Listeria spp. $[14,18-20]$. Plankton also produces organic carbons in the aquatic environment [21]. These organic carbons-particulate organic carbon (POC) and dissolved organic carbon (DOC)-in the seawater provide favourable growing conditions for the bacteria [22]. DOC is regarded as the organic carbon that passes through a $0.2-0.45 \mu \mathrm{m}$ membrane filter, while POC is retained [14]. However, in Norway deep seawater is still used in order to secure a stable temperature and salinity throughout the year. The inlet seawater in the hatchery must be treated in order to prevent the outbreak of diseases, pathogens and toxic substances $[23,24]$. Different treatment methods (ozone, ultraviolet (UV) light, filtration, protein skimmers, disinfectant and antibiotics) are used in hatcheries [25,26].

The flow-through system has proved to be successful and costeffective in larval rearing without the use of antibiotics and has shown success at the Scalpro AS hatchery [9]. However, the seawater quality is not stable. This affects spat and larval development and survival $[9,13]$.

${ }^{*}$ Corresponding author: Thorolf Magnesen, Department of Biology, University of Bergen, P.O Box-7803, N-5020 Bergen, Norway, E-mail: Thorolf.Magnesen@bio.uib.no

Received October 01, 2012; Accepted December 18, 2012; Published December 28, 2012

Citation: Magnesen T, Jacobsen A, Moepi MH (2013) Effect of Different Filter Methods on Seawater Quality at a Marine Scallop Hatchery. J Aquac Res Development 4:168 doi:10.4172/2155-9546.1000168

Copyright: (c) 2013 Magnesen T, et al. This is an open-access article distributed under the terms of the Creative Commons Attribution License, which permits unrestricted use, distribution, and reproduction in any medium, provided the original author and source are credited. 
Mechanical filters are often used to remove particles in the hatcheries as TOC accumulation has an impact on seawater quality and the efficiency of filters $[27,28]$. The AFM is composed of reprocessed glass with a surface area for bacterial growth and allows the removal of TOC. It operates both biologically and mechanically, as well as being selfsterilizing (www.afm.eu). The drum filter (DF) removes the suspended solids by rotating the drum while backwashing and removing the waste from the filter [29]. The DF is commonly used in the recirculating system for marine fish hatcheries more than in shellfish hatcheries [30]. The use of mechanical filters in marine shellfish hatcheries is less widely explored and studied [31]. Therefore, the use of a drum filter, however superficially explored, may serve as an alternative in treating the seawater and larval rearing [23]. Protein skimmers in marine hatcheries have proven to be efficient in reducing DOC and fine particles in seawater [32]. By using filters and protein skimmers in the hatchery, a larger amount of the organic material will be removed from the inlet seawater, at the same time reducing the threat of opportunistic bacteria.

The main objective of the present study was to investigate the effect of different seawater treatments on the quality of marine seawater used in the hatchery production of great scallop ( $P$. maximus) larvae. We used two treatments: active filter media and drum filter, both equipped with protein skimmers, and investigated the effect on the chemical and microbial characteristics of seawater, egg development to day 3 larvae, larval activity and growth of microalgae. The main background for comparing the two methods of seawater treatment was the occasional failure in scallop larval survival [13].

\section{Materials and Methods}

Samples for seawater characteristics were collected from the experimental set-up at the scallop hatchery Scalpro AS in Hordaland, Norway on 10 March, 14 April and 11 May 2009. The effect studies (egg development, larval activity and algal growth) were performed in the following weeks (11-20 March, 15-25 April and 12-23 May 2009). The main seawater inlet was located in Hjeltefjorden in Norway at a depth of $120 \mathrm{~m}$ in March and April and a depth of $60 \mathrm{~m}$ in May. Seawater samples were collected from the seawater inlet (sampling point P1). The seawater was separated into two different treatment lines. One consisted of a sand filter with active filter media (AFM, sampling point P2) followed by a protein skimmer (Sander Aquarietechnik, Helgoland 500, Uetze-Eltze, Germany, sampling point P3). The other line consisted of a drum filter (DF) with a $10 \mu \mathrm{m}$ screen mesh (Hydrotech model HDF 1604-3H, Vellinge, Sweden, sampling point P4) followed by another Helgoland protein skimmer (sampling point P5).

\section{Seawater quality parameters}

Temperature $\left({ }^{\circ} \mathrm{C}\right)$, salinity $(\%)$ and dissolved oxygen (DO $\mathrm{mg} \mathrm{L}^{-1}$ and $\%)$ were sampled from all sampling points (P1-P5). The measurements were taken once a month in March, April and May. The temperature, salinity and DO were all determined using a digital multimeter (WTW multi 197i Oximeter) following Standard Method 2810 [33]. DO was measured both as DO $\left(\mathrm{mg} \mathrm{L}^{-1}\right)$ and as DO (\%). Total organic carbon (TOC, $\mathrm{n}=1$ ) and dissolved organic carbon (DOC, $\mathrm{n}=3$ ) samples were taken from all sampling points (P1-P5). Samples for DOC were prefiltered using $0.45 \mu \mathrm{m} \mathrm{GF/F} \mathrm{membrane} \mathrm{filters.} \mathrm{Samples} \mathrm{were} \mathrm{analysed}$ by Chemlab Services AS according to Norwegian Standard 1484 (1997) using a total organic carbon analyser (TOC-5000, Shimadzu) equipped with a sample exchanger (ASI-5000, Shimadzu) and TOC control (Shimadzu Corp, Version 1.05.01). Organic carbon was converted to carbon dioxide $\left(\mathrm{CO}_{2}\right)$ when heated at $680^{\circ} \mathrm{C}$ including the oxidizing platinum catalyst. The combustion product was transported by pure air passing through the inorganic carbon container into an infrared (IR) detector.

Total bacteria number was estimated from three replicate seawater samples $(1.5 \mathrm{~mL})$ collected from all sampling points (P1-P5). The samples were frozen in Eppendorf tubes at $-80^{\circ} \mathrm{C}$ containing $40 \mu \mathrm{L}$ glutaraldehyde $(0.25 \%$ of final concentration). The samples were thawed and serially diluted with $0.2 \mu \mathrm{m}$ filtered sterile seawater to 1:05, 1:10 and 1:50. The diluted samples were stained with molecular probes, SYBR Green I and analysed using CELLQuest software version 3.0 [34] and a FACSCalibur flow cytometer (Becton Dickinson). Vibrio spp. bacteria were cultured on Thiosulfate Citrate Bile Sucrose (TCBS) agar (specific for Vibrio spp.) (Merck Cat. No. 1.10263) and expressed as colony forming units (CFU ml-1). Samples (in triplicates) were taken from all sampling points (P1-P5).

Bacterial composition was analysed from seawater samples (1 L) from all sampling points (P1-P5). The samples were filtered through 5 $\mu \mathrm{m}$ filters to remove larger particles and then filtered through $47 \mathrm{~mm}$ polycarbonate filters, pore size $0.2 \mu \mathrm{m}$ (Whatman ${ }^{\circledR}$, Schleider \& Schuell, UK). The filtered samples were frozen at $-20^{\circ} \mathrm{C}$ and analysed according to Sandaa et al. [35] Deoxyribonucleic acid (DNA) was extracted and the bacteria harvested were used as templates in a polymerase chain reaction (PCR) performed in a GeneAmp PCR System 2400 (Perkin Elmer) and thermal cycler (Applied Biosystems 2720). Denaturing gradient gel electrophoresis (DGGE) provided the profile of the bacterial community by analysing the PCR products. The sequencing was done at the SARS centre (Bergen, Norway) using Big-Dye protocol version 3.1 (http://seqlab.uib.no) on an ABI Prism 377 DNA sequencer, and further analysing the sequences using Invitrogen software. A cluster diagram was made for different sampling months and for comparisons of bacterial community composition.

\section{Scallop egg development}

Pecten maximus broodstock from western Norway was conditioned and spawned according to standard protocols. Experiments for testing egg development to 3 day old larvae (D3) were set up using seawater from the AFM+skimmer (P3) and the DF+skimmer (P5). Fertilized eggs were transferred to $10 \mathrm{~L}$ buckets at a density of approximately 100,000 bucket-1 without any algal feed, but gentle mixing with air bubbles, and counted after 3 days. A $50 \mu \mathrm{L}$ sample of retained larvae was counted 5 times using an inverted stereo microscope.

\section{Larval activity}

Larval activity was tested using 8 day old larvae in seawater qualities from the AFM+skimmer (P3) and DF+skimmer (P5). The tests were replicated three times in order to account for variation in the number of larvae per well. The 12-well polystyrene multi-dish (Nunc) was filled with $2 \mathrm{~mL}$ of SSW, and approximately 20 to 30 larvae were placed in each well and then inoculated with $100 \mu \mathrm{L}$ of undiluted seawater from the AFM+skimmer (P3) or DF+skimmer (P5). Dilution series of 1:10 and 1:100 were used. Incubation of larvae was performed in a dark place at $18^{\circ} \mathrm{C}$ in an air-conditioned room. After 48 hours, the number of moving or active larvae from all wells was counted using an inverted stereoscopic microscope (Leitz DM IL) according to the protocol in Torkildsen et al. [12] and Sandlund et al. [36]. The wells were counted twice to reduce counting errors.

\section{Microalgal cell numbers}

The microalgae, Chaetoceros muelleri (CHM-strain CCAP 1010/3), were grown in $2 \mathrm{~L}$ volume using seawater from the AFM+skimmer 
Citation: Magnesen T, Jacobsen A, Moepi MH (2013) Effect of Different Filter Methods on Seawater Quality at a Marine Scallop Hatchery. J Aquac Res Development 4:168 doi:10.4172/2155-9546.1000168

Page 3 of 8

(P3) and DF+skimmer (P5). The seawater samples were autoclaved at $120^{\circ} \mathrm{C}$ for approximately 20 minutes before use. The stock culture (30 $\mathrm{mL})$ were grown and maintained under continuous white fluorescent light (Osram L 58W/965 Biolux) at $100 \pm 2 \mu \mathrm{mol} \mathrm{m} \mathrm{m}^{-2}, 15^{\circ} \mathrm{C} \pm 1^{\circ} \mathrm{C}$ and in Conway medium according to Laing [37]. The algae $(2 \mathrm{~L})$ were grown under the same light conditions, but at $20^{\circ} \mathrm{C} \pm 1^{\circ} \mathrm{C}$. Aeration was added in the culture supplemented with carbon dioxide. Algal growth was followed for 4-5 days.

\section{Statistical analysis}

Data were analysed using one-way analysis of variance (ANOVA) in STATISTICA 10. All statistical tests were carried out at a 0.05 significance level.

\section{Results}

\section{Seawater quality parameters}

The temperature of the incoming seawater increased from $7.4^{\circ} \mathrm{C}$ in March to $8.7^{\circ} \mathrm{C}$ in May. The mean temperature in the protein skimmers were significantly higher than in the other sampling points $(p=0.00)$. The average temperature in protein skimmer after AFM (P3) was $12.7^{\circ} \mathrm{C}$, while it in the protein skimmer after the DF-filter was $8.9^{\circ} \mathrm{C}$ (P5). Salinity was always between 34.9 and 35.0. Dissolved oxygen in incoming seawater was between $8.9 \mathrm{mg} \mathrm{L}^{-1}(75.7 \%)$ and $10.8 \mathrm{mg} \mathrm{L}^{-1}$ $(88.0 \%)$, and increased in the protein skimmers to a maximum of 12.7 $\mathrm{mg} \mathrm{L}^{-1}(110.6 \%)$. No significant differences were found in oxygen levels between the other sampling points measured as saturation $(\mathrm{p}=0.39)$ or concentration $(\mathrm{p}=0.06)$.

Total organic carbon (TOC) in the incoming seawater was dominated by content of dissolved organic carbon (DOC). TOC concentrations in the incoming seawater increased from $4.0 \mathrm{mg} \mathrm{L}-1$ in March to $4.9 \mathrm{mg} \mathrm{L}^{-1}$ in May, and the DOC content constituted 3.5 (87 $\%$ ) and $4.7 \mathrm{mg} \mathrm{L}^{-1}$ (98\%). The DOC concentrations were usually highest in the inlet water and AFM filter, and significant reductions were found after the protein skimmers, particularly the skimmer after the drum filter (P5, Figure 1). In April there was a significant increase in DOC in the AFM filter. In May DOC was reduced with all treatments, and the DOC concentration at P5 was significantly $(\mathrm{p}=0.01)$ lower than at P3. On average, the DOC concentration present in inlet seawater was reduced by $31 \%$ by the AFM+skimmer (range $23-36 \%$ ) and by $34 \%$ by the DF+skimmer (range 28-45\%).

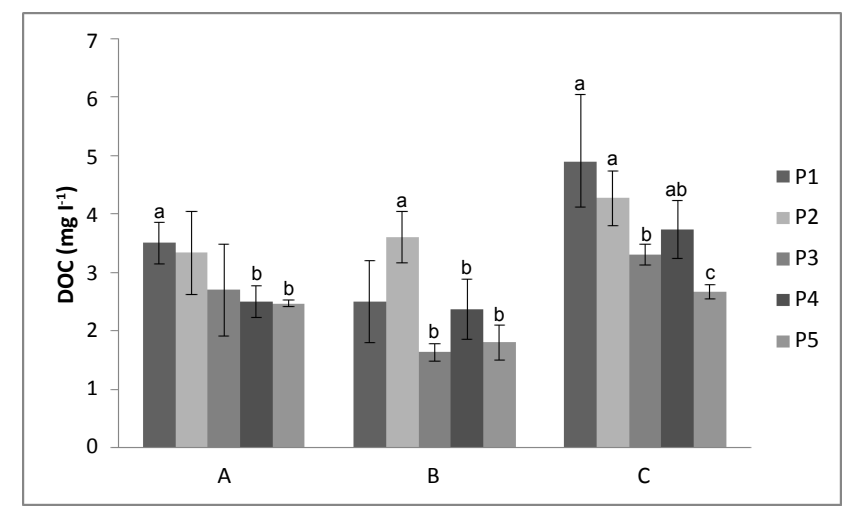

Figure 1: Concentration of dissolved organic carbon (DOC, $\mathrm{mg} \mathrm{l}^{-1}$ ) at five sampling points (P1-P5) in March (A), April (B) and May (C) 2009. Error bars indicate mean $(n=3) \pm$ STD. Bars with different letters are significant different $(p<0.05)$.

\section{Bacterial communities}

The total bacterial cell numbers (TBN) were lowest in March, and there were small variations in April and May (Figure 2). In March the bacterial cell number $\left(2.3 \times 10^{5}\right.$ cells $\left.\mathrm{mL}^{-1}\right)$ in the inlet seawater $(\mathrm{P} 1)$ increased after the DF (P4), but was significantly reduced after the skimmer (P5, $\mathrm{p}=0.01)$. In April and May both treatments (AFM and DF) maintained similar bacterial cell numbers $\left(3.7 \times 10^{5}\right.$ cells $\left.\mathrm{mL}^{-1}\right)$ to the inlet seawater (P1), and there was no significant difference between treatments $(\mathrm{p}=0.28(\mathrm{P} 3)$ and $\mathrm{p}=0.11(\mathrm{P} 5)$.

TCBS samples were taken in triplicate in March, April and May from all sampling points (P1-P5). Vibrio spp. colonies (Table 1) varied between 0 and more than $70 \mathrm{CFU} \mathrm{mL}^{-1}$. In March Vibrio spp. was only found in one sample from the drum filter. In April and May it was found at most sampling points. No colonies were observed in seawater coming from the skimmer after the drum filter (P5).

Based on the denaturing gradient gel electrophoresis (DGGE-not shown), a profile of the bacterial community was produced by analysing the PCR products from all sampling points. The strongest bands were

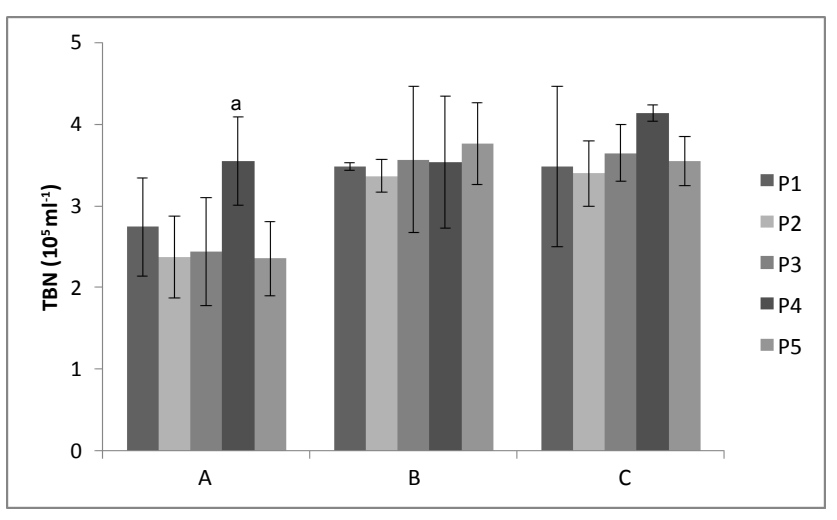

Figure 2: Total bacterial numbers (TBN, $105 \mathrm{ml}-1$ ) in five sampling points ( $\mathrm{P} 1$ $P 5)$ in March (A), April (B) and May (C). Error bars indicate mean $(n=10) \pm$ STD Bars with different letters are significant different $(p<0.05)$.

\begin{tabular}{|l|l|l|l|l|}
\hline & & March & April & May \\
\hline 1 & a,b,c & $0,0,0$ & $0,20,20$ & $0,0,10$ \\
\hline 2 & a,b,c & $0,0,0$ & $0,40,>70$ & $0,20,20$ \\
\hline 3 & a,b,c & $0,0,0$ & $20,40,70$ & $0,0,10$ \\
\hline 4 & a,b,c & $0,0,40$ & $10,10,20$ & $0,10,20$ \\
\hline 5 & a,b,c & $0,0,0$ & $0,0,0$ & $0,0,0$ \\
\hline
\end{tabular}

Table 1: Numbers of CFU $\mathrm{ml}^{-1}$ on TCBS agar in samples $(a, b, c)$ at sampling points 1 to 5 on 10 March, 14 April and 11 May 2009.

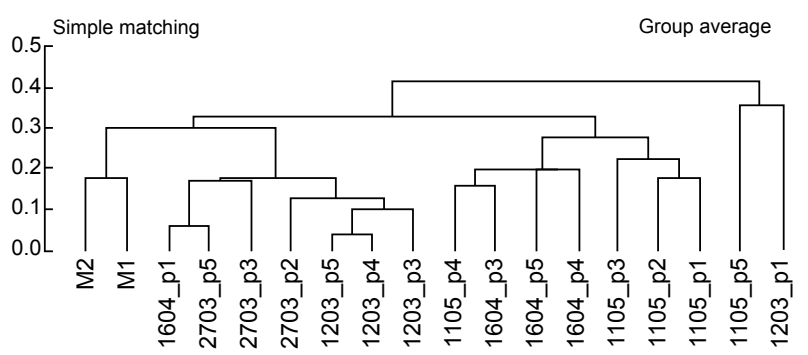

Figure 3: Cluster-analyses of DGGE gel with samples from the Scalpro AS hatchery. Dates are given. M1 and M2 are markers. The analyses were made only from bands that were good from different sampling points at different months. 
Citation: Magnesen T, Jacobsen A, Moepi MH (2013) Effect of Different Filter Methods on Seawater Quality at a Marine Scallop Hatchery. J Aquac Res Development 4:168 doi:10.4172/2155-9546.1000168

used for sequencing and cluster analysis (Figure 3). Commonly found sequences found in bands from the DGGE gel were compared by simple matching from Genbank (Table 2). A marine bacterioplankton community commonly found in natural seawater could be seen. Many of the sequences belong to Alpha-and Gammaproteobacteria and to Actinobacteria. Most sequences were found in samples from P3 and P5. More sequences of Actinobacteria were found in seawater passing through the AFM (P3) than through the drum filter (P5). Also, the Actinobacteria were most prominent in March (A) compared to the Gammaproteobacteria and other bacterial strains found.

The cluster diagram grouped sampling points sampled on the

\begin{tabular}{|c|c|c|}
\hline In sample & Similar to & Accession no \\
\hline $\mathrm{P} 1(\mathrm{~B})$ & $\begin{array}{l}\text { Uncultured gamma proteobacterium clone PM1-27 (98\%); } \\
\text { Oceaniserpentilla haliotidis (94\%) }\end{array}$ & $\begin{array}{l}\text { EF215799 } \\
\text { AM747817 }\end{array}$ \\
\hline $\mathrm{P} 1(\mathrm{~B})$ & $\begin{array}{l}\text { Colwellia maris strain ABE-1(92\%) } \\
\text { Uncultured bacterium clone HC-8 (92\%) }\end{array}$ & $\begin{array}{l}\text { NR_024635 } \\
\text { AY529875 }\end{array}$ \\
\hline $\mathrm{P} 1(\mathrm{~B})$ & Uncultured bacterium clone HF130_D6_P1 (94\%) & DQ300613 \\
\hline $\mathrm{P} 1(\mathrm{C})$ & Uncultured gamma proteobacterium clone PM1-27 & EF215799 \\
\hline $\mathrm{P} 2(\mathrm{~A})$ & $\begin{array}{l}\text { Unidentified alpha proteobacterium OM75 (90\%) } \\
\text { Nisaea nitritireducens strain DR41_18 (88\%) }\end{array}$ & $\begin{array}{l}\text { U70683 } \\
\text { DQ665839 }\end{array}$ \\
\hline P2 $(A, B)$ & $\begin{array}{l}\text { Uncultured Chloroflexaceae group bacterium } \\
\text { Arctic96BD-6 (93\%) }\end{array}$ & AF355053 \\
\hline $\mathrm{P} 2(\mathrm{~A})$ & $\begin{array}{l}\text { Uncultured gamma proteobacterium clone PM1-27 } \\
(99 \%) ; \\
\text { Oceaniserpentilla haliotidis (94\%) }\end{array}$ & $\begin{array}{l}\text { EF215799 } \\
\text { AM747817 }\end{array}$ \\
\hline $\mathrm{P} 2(\mathrm{~A})$ & $\begin{array}{l}\text { Uncultured organism clone ctg_NISAA66 (99\%) } \\
\text { Uncultured Candidatus Microthrix sp. clone } \\
\text { BATS136-250-93 }\end{array}$ & $\begin{array}{l}\text { DQ396300 } \\
\text { FJ960805 }\end{array}$ \\
\hline $\mathrm{P} 2(\mathrm{C})$ & Uncultured bacterium clone HF130_D6_P1 (94\%) & DQ300613 \\
\hline $\mathrm{P} 2(\mathrm{C})$ & $\begin{array}{l}\text { Uncultured bacterium clone Mann16S_G10B } \\
(100 \%)\end{array}$ & FJ952689 \\
\hline P3 (A) & Uncultured SAR11 cluster alpha proteobacterium & AM748185 \\
\hline P3 (A) & Uncultured SAR11 cluster alpha proteobacterium & DQ186916 \\
\hline P3 (A) & $\begin{array}{l}\text { Uncultured marine bacterium clone BM1-F-105 } \\
(82 \%)\end{array}$ & FJ826203 \\
\hline P3 (A) & $\begin{array}{l}\text { Uncultured marine bacterium clone BM1-8-74 } \\
(99 \%)\end{array}$ & FJ826062 \\
\hline P3 (A) & Uncultured gamma proteobacteriumFFW81 (99\%) & AY830024 \\
\hline P3 (A) & $\begin{array}{l}\text { Uncultured actinobacterium clone HF4000_16H14 } \\
(98 \%)\end{array}$ & EU361019 \\
\hline P3 (B) & $\begin{array}{l}\text { Uncultured gamma proteobacterium clone } \\
\text { GC21V_AD (95\%) }\end{array}$ & AY701419 \\
\hline P3 (C) & $\begin{array}{l}\text { Uncultured bacterium clone Mann16S_G10B } \\
(100 \%)\end{array}$ & FJ952689 \\
\hline $\mathrm{P} 4(\mathrm{~B}, \mathrm{C})$ & $\begin{array}{l}\text { Uncultured gamma proteobacterium clone } \\
\text { GC21V_AD }(95 \%)\end{array}$ & AY701419 \\
\hline $\mathrm{P} 4(\mathrm{C})$ & $\begin{array}{l}\text { Uncultured bacterium clone Mann16S_G10B } \\
(100 \%)\end{array}$ & FJ952689 \\
\hline P5 (B) & $\begin{array}{l}\text { Uncultured gamma proteobacterium clone } \\
\text { GC21V_AD }(95 \%)\end{array}$ & AY701419 \\
\hline P5 (C) & Sphingomonas melonis strain PR-3 & FJ605424 \\
\hline P5 (C) & $\begin{array}{l}\text { Uncultured marine bacterium clone BM1-8-74 } \\
(97 \%)\end{array}$ & FJ826062 \\
\hline P5 (C) & Colwellia rossensis strain ANT9279 $(98 \%)$ & AY167311 \\
\hline P5 (C) & $\begin{array}{l}\text { Uncultured bacterium clone Mann16S_G10B } \\
(100 \%)\end{array}$ & FJ952689 \\
\hline P5 (C) & $\begin{array}{l}\text { Uncultured Rhodobacteraceae bacterium clone } \\
\text { IG3E05 }\end{array}$ & FJ718205 \\
\hline P5 (C) & Uncultured marine bacterium clone ArtRif4-2 & FJ594812 \\
\hline P5 (C) & $\begin{array}{l}\text { Uncultured alpha proteobacterium clone } \\
\text { HF130_15B09; } \\
\text { Uncultured bacterium clone 2C228359 }\end{array}$ & $\begin{array}{l}\text { EU361386 } \\
\text { EU800311 }\end{array}$ \\
\hline
\end{tabular}

Table 2: Dominant sequences found in bands from DGGE-gel (not shown) with simple matching from Genbank in samples from sampling points P1-P5 in March (A), April (B) and May (C). same date and over time. The bacterial composition changed over time (Figure 3) in all sampling points. A succession both through the season and between treatments could be observed. It seemed that sampling point P5 was most similar to the seawater inlet samples (P1) and less similar to the other samples. The samples from March were grouped together with inlet seawater in April, while the other samples from April formed one group and subsequently grouped with the May samples. The highest matching was found between inlet seawater in March and after the drum filter and skimmer (P5) in May.

\section{Egg development and larval activity}

Egg development, as the fraction of D3 larvae from eggs, increased from March to May (Figure 4). It was low in March and April ( $<20 \%)$, but high $(>50 \%)$ in May in both treatments, but no significant differences was found. Larval activity was lowest in March and showed some increase in April and May (Figure 5). In March no significant difference was found between the two treatments. In April significant higher larval activities were observed in undiluted $(\mathrm{p}=0.02)$ and 100 -fold diluted $(\mathrm{p}=0.03)$ seawater samples coming from the protein skimmer after the drum filter (P5). In May the same significant ( $p=0.04)$ increase was found in the 100-fold diluted sample.

\section{Algal growth}

Chaetoceros muelleri was grown in March, April and May using seawater from skimmer P3 and skimmer P5. The cell numbers were counted from day 1 until the exponential phase finished (Figure 6). Growth rates $(\mu)$ increased from March to May, being 0.75-0.83, 0.951.14 and $1.10-1.15$, respectively. No significant difference in algal concentration was found between the two seawater treatments during the first 4-5 days.

\section{Discussion}

\section{Environmental factors}

The results obtained in this study did not show any significant changes in egg development, larval activity or growth of microalgae that could be related to the different water treatments. We observed, however, a clear seasonal change in the results reflecting the environmental changes that occurred during early spring events. Significant changes due to water treatments were also observed in the content of DOC and the occurrence of potential lethal bacterial.

In scallop hatcheries, one of the main problems is larval survival

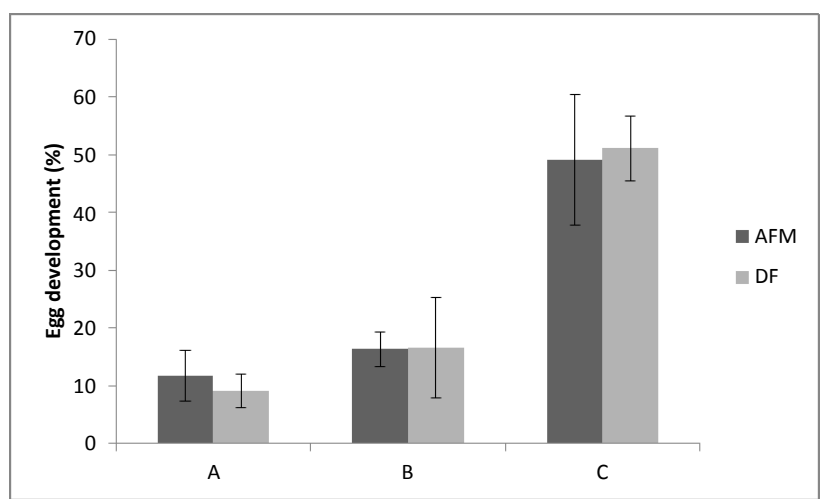

Figure 4: Egg development to day 3 larvae (\%) in March (A), April (B) and May (C) 2009. AFM=incubated in water from AFM+skimmer, DF=incubated in water from drum filter and skimmer. Error bars indicate mean $(n=5) \pm$ STD. 

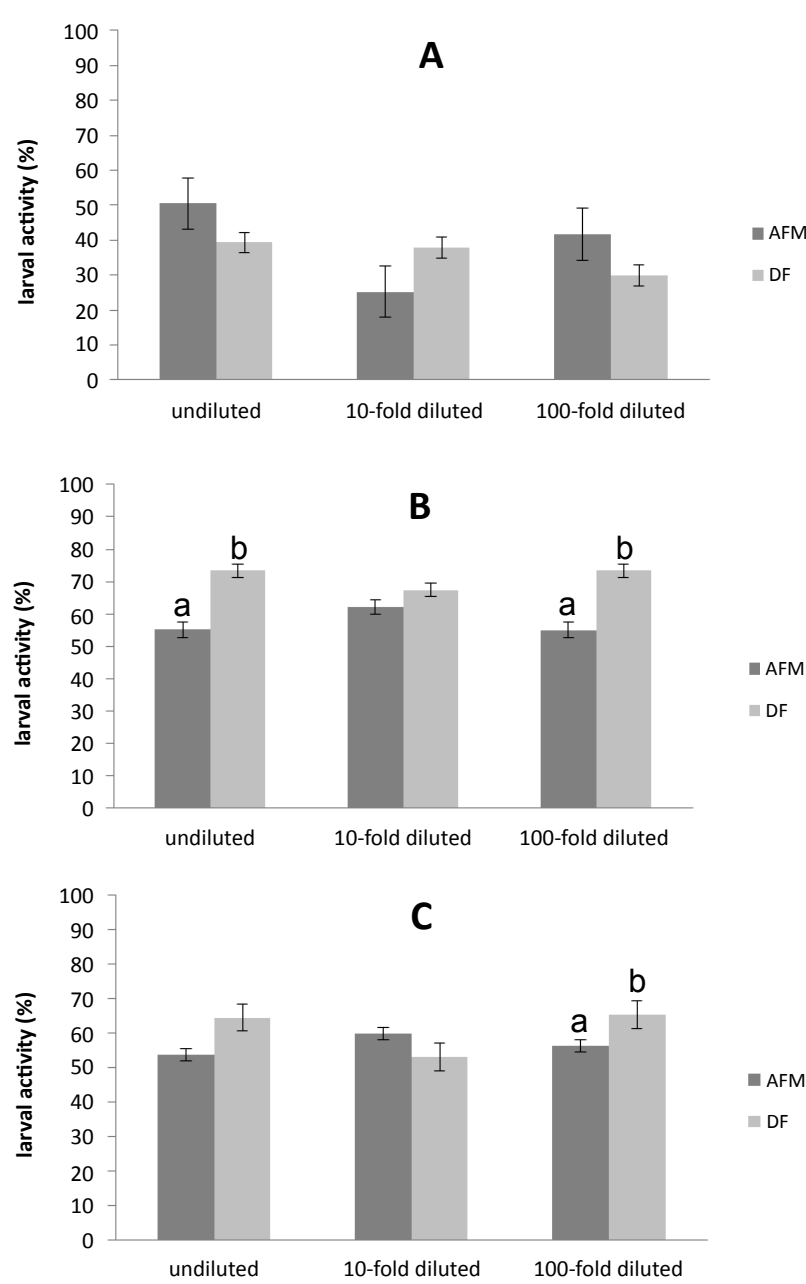

DF

Figure 5: Larval activity (\%) of scallop larvae after 48 hours exposure to undiluted, 10 -fold diluted and 100 -fold diluted water from AFM and drum filter (DF) in March (A), April (B) and May (C) 2009. Error bars indicate mean $(n=3) \pm$ STD. Bars with different letters are significant different $(p<0.05)$.

that may limit the production of spat [13]. Mortalities are often associated with opportunistic bacteria, but may also be due to traces of inhibitory or toxic substances sporadically occurring in the water supply [11,12,38-41]. Bacterial blooms benefit from increased organic carbon concentrations and the major bacteria sources are inlet water, algal production and brood stock [42]. Seawater quality is given the highest importance and is the single most important factor for hatchery site selection, and ideally solids and dissolved substances should be absent [43]. It should, however, also be recognized that dissolved organic material may be utilized by bivalve larvae Manahan [44], bacteria are an important source Wakeham et al. [45], and bacteria may also be an important part of the larval diet [46].

Marine hatcheries located in Norway usually have the deep water inlet located at a depth of 60-180 m. The main reason is to avoid seasonal variations in temperature, salinity and organic production occurring in the surface layer. Dissolved organic carbon (DOC) compounds in deep water are less than half that in surface layers, but little is known of their composition and accumulation [47-49]. In the Trondheimsfjord in Norway, DOC in deep water accumulated during the productive season and had maximum concentrations in spring and summer [50].
The high fraction of DOC (70-90 \%) was reasonable Chrzanowski et al. [51] , but the values may seem a bit higher than what are considered typical values of DOC in oxygen-bearing water (1.0-1.2 $\mathrm{mg} \mathrm{L}^{-1}$, Adams \& Richards 1968) [52], in the deep water masses of the Trondheimsfiord $\left(<1.2 \mathrm{mg} \mathrm{L}^{-1}\right.$, Børsheim et al. [50] and in other north Norwegian fjords (1.5-2.5 mg L-1 A. Jacobsen pers. comm.). The organic load may, however, differ with depth and location [53]. The presence of particulate material serves as an important substrate for bacterial attachment (Garneau et al. [54], and DOC as an important source for bacterial production $[55,56]$. Both seawater treatments significantly reduced the content of DOC. On average, the content was reduced by $30-35 \%$. These figures were low compared to what may be obtained in recirculation systems where as much as $60-100 \%$ may be removed, but higher than observed by Park et al. [57] who used addition of ozone to increase DOC removal efficiency [28,32].

The total available organic carbon in a hatchery should be kept low without large fluctuations. In our experiment, DOC increased from March to May. This is the period when the local spring phytoplankton bloom occurs in surface water [58]. Both of the water treatments used
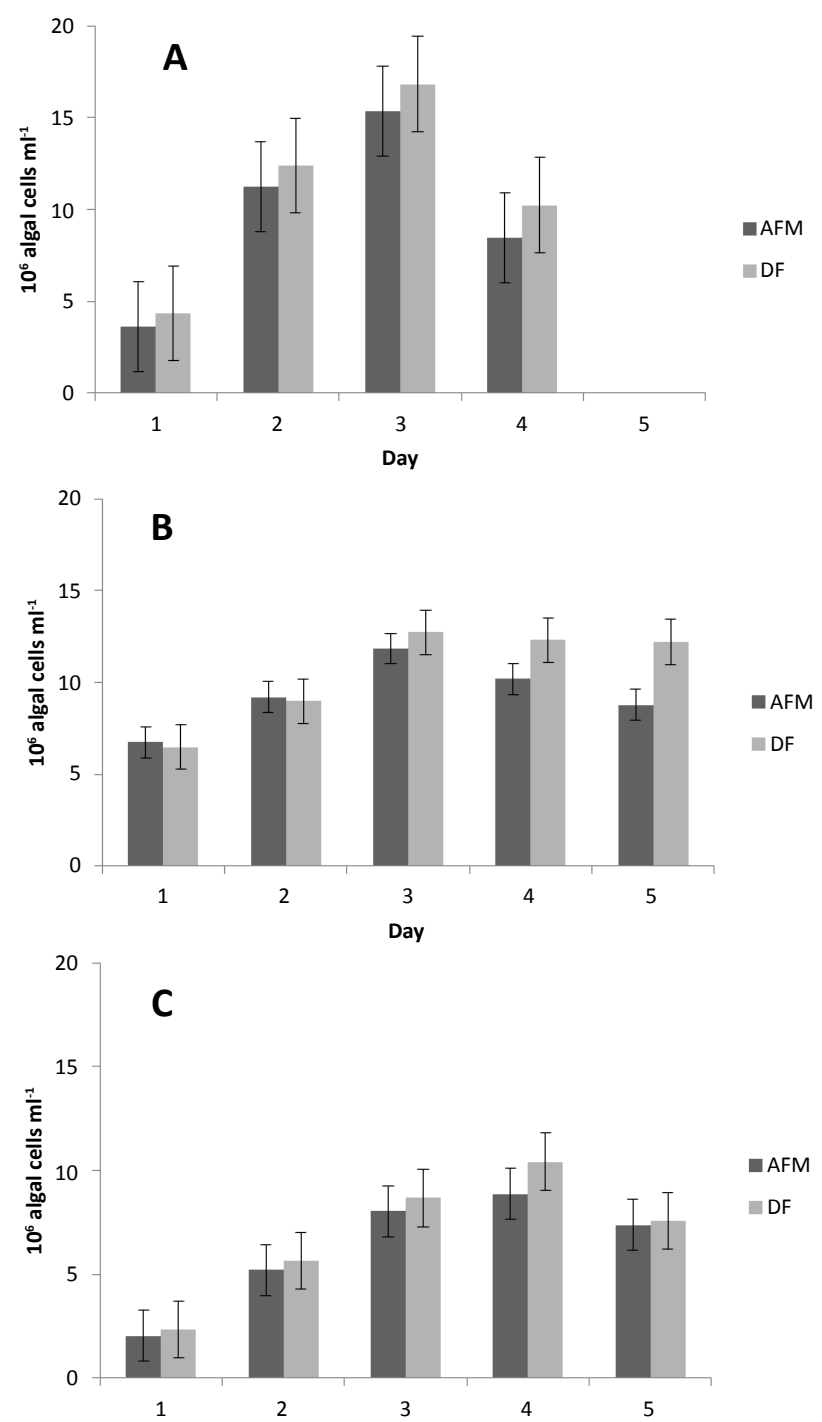

Figure 6: Algal cell numbers $\left(10^{6} \mathrm{ml}^{-1}\right)$ has grown in different water qualities (AFM and DF) in March (A), April (B) and May (C). Error bars indicated mean $(n=3) \pm$ S.E. Bars with different letters are significant different $(p<0.05)$. 
significantly decreased the DOC content and evidently the use of a drum filter and protein skimmer was the most effective. This could be explained by the backwashing action of the drum filter [59]. The drum filter is known to remove both small and large components of the organic material, and even large or small solids from the water $[27,28]$. The use of a biofilter such as Active Filter Media (AFM) in the flow-through system may serve as a major substrate for heterotrophic bacteria in the hatchery because it traps DOC and POC on the filter [60]. In May, the low reduction of DOC by the AFM+skimmer may have favoured opportunistic bacteria as seen from the DGGE profile, where the Gamma proteobacteria became dominant.

The total bacterial numbers found in this study were within the typical range found in seawater $\left(10^{3}-10^{6}\right.$ cells $\left.\mathrm{mL}^{-1}\right)$ and marine hatcheries $[61,62]$. The total bacterial number increased from 2.5 to 3.5 $10^{5} \mathrm{~mL}^{-1}$ from March to April, and no significant decrease was obtained with the water treatments. Instead we found an elevated number of bacteria in the drum filter in March, but this was significantly reduced by the skimmer. Even though the overall bacterial number did not change, a change in bacterial composition may have occurred [63], as also seen from the cluster analysis in our study. The cluster analysis reflected a seasonal change in bacterial composition and clearly separated samples collected in March from the April and May samples. The samples collected from water after skimmer and drum filter showed least similarity to the other samples. This was particularly obvious in May when grouped together with a sample obtained from the water inlet in March. Low bacterial numbers may not always be beneficial in marine larval production systems [62]; they are more dependent on an even and diverse microbial community structure $[62,64]$.

The most common sources of Vibrio spp. in the hatchery are algal cultures and introduction with brood stock [42]. We found Vibrio spp. colonies in March associated with the maximum total bacterial number in the drum filter. In April and May Vibrio spp. were found in the water inlet, AFM, DF and the skimmer after the AFM, but never in water coming from the skimmer after the drum filter. All figures must be considered low. Lewis et al. [65] suggested that seawater must contain less than $100,000 \mathrm{CFU} \mathrm{mL} \mathrm{mL}^{-1}$ for safe use in bivalve hatcheries. This was supported by Abasolo-Pacherco et al. [23], who found little effect of Vibrio spp. on larval survival, but specific studies with $V$. alginolyticus have shown significant effects at 0.002 cells $\mathrm{mL}^{-1}$ [66]. Increased scallop larval mortality has been observed when challenged with $V$. splendidus at higher concentrations $\left(10^{7}-10^{9}\right.$ cells $\mathrm{mL}^{-1}[36]$.

DGGE analysis has previously been used to characterize bacterial communities in a scallop hatcher[35], who found a change in composition in samples from a pipe inlet but a high stability in composition in larval tanks. A high fraction of the bacteria (53\%) were similar to the gamma subclass of Proteobacteria, as observed by Jorquera et al. [62] in hatcheries in Chile. Brunvold et al. [67] concluded that DGGE was a suitable method for characterizing bacterial communities in hatcheries, but genes other than $16 \mathrm{rDNA}$ should be used for the discrimination of closely related taxa, like different Vibrio spp.

\section{Effects on egg development, larval activity and algal growth}

The development from egg to D3 larvae $(<20 \%$ in March and April) were low compared to the large-scale development of eggs in the hatchery's commercial spawning groups during the same period (35-46\%, T. Magnesen, pers. comm.). Normally about $30 \%$ of the eggs will develop into D3 larvae [10]. The differences could be due to the selection of a small number of eggs coming from only a few broodstock. We did not find any effect of water treatment on the fraction of eggs that developed into D3 veliger larvae at any sampling date, indicating that water quality did not affect their development.

In this study, no significant changes were observed in larval activity related to the different water treatments, except for undiluted (April) and 100-fold dilution (April and May) from the drum filter, when larval activity was significant higher. The higher larval activity detected with water passing through the drum filter could therefore indicate better water quality for the young larvae from this water treatment. This method for studying larval activity was also used by Sandlund et al. [36] and was found to be useful in a challenge test with pathogenic Vibrio bacteria. Sandlund et al. [36] also found no difference in larval mortality challenged with different bacterial strains, with mortality averaging $25 \%$.

We found no significant effect of the seawater treatments on microalgal growth growth rates decreased as spring progressed. This may be due to inhibitory substances secreted by other spring bloom species [68] or algal-associated bacteria. It has been found that high counts of opportunistic and haemolytic bacterial species were associated with Bacillariophyceae, the class to which C. muelleri belongs [69]. Hattenrath-Lehmann and Gobler [70] also found that growth of diatoms was inhibited by the dinoflagellate Alexandrium fundyense. Species from the genus Alexandrium have been found to have an allelopathic effect on the natural phytoplankton bloom in Norwegian waters by decreasing the growth rate [71]. It has also been shown that polyunsaturated aldehydes derived from Skeletonema marinoi, a common spring bloom species in Norwegian waters, may also trigger the declining phase of algal growth [72].

\section{Conclusion}

We therefore conclude that the use of drum filter and protein skimmer was most effective in reducing dissolved organic carbon and Vibrio spp. bacteria in the seawater and increased larval activity. We did, however, not find any significant effects from the different water treatments on egg development or growth of microalgae. A seasonal variation from winter to spring was found for egg development and larval activity (increasing), and algal growth rates (decreasing). Reducing dissolved organic substances and potentially lethal bacteria is an important prerequisite for hatchery management.

\section{Acknowledgements}

We would like to thank Scalpro AS hatchery staff members Anne Grete Dale, Eivind Rong and Johnny Rong. This project was financially supported by Scalpro AS and the Regional Council for Western Norway.

\section{References}

1. Strand $\varnothing$, Parsons, GJ (2006) Scandinavia, in: Shumway SE, Parsons G (Eds) Scallops: Biology, Ecology and Aquaculture, Elsevier press: 1067-1091.

2. Bergh $\varnothing$, Strand $\varnothing$ (2001) Great scallop, Pecten maximus, research and culture strategies in Norway: a review. Aquaculture International 9: 305-317.

3. Brand AR (2006) Scallop ecology: distribution and behaviour, in: Shumway SE Parsons GJ, (eds). Scallops: biology, ecology and aquaculture, Elsevier press: 651-744.

4. Christophersen G Magnesen T (2001) Effects of deployment time and acclimation on survival and growth of hatchery-reared scallop (Pecten maximus) spat transferred to the sea. Journal of Shellfish Research 20: 10431050.

5. Avendaño M, Cantillánez MS, Thouzeau G, Peña JB (2007) Artificial collection and early growth of spat of the scallop Argopecten purpuratus (Lamarck, 1819), in La Rinconada Marine Reserve, Antofagasta, Chile. Sci Mar 71: 195-205.

6. Marshall R, McKinley S Pearce CM (2010) Effects of nutrition on larval growth and survival in bivalves. Reviews in Aquaculture 2: 33-55 
Citation: Magnesen T, Jacobsen A, Moepi MH (2013) Effect of Different Filter Methods on Seawater Quality at a Marine Scallop Hatchery. J Aquac Res Development 4:168 doi:10.4172/2155-9546.1000168

Page 7 of 8

7. Christophersen G (2000) Effects of air emersion on survival and growth of hatchery reared great scallop spat. Aquaculture International 8: 159-168.

8. Magnesen T, Christophersen G (2008) Reproductive cycle and conditioning of translocated scallops (Pecten maximus) from five broodstock populations in Norway. Aquaculture 285: 109-116.

9. Magnesen T, Bergh Ø, Christophersen G (2006) Yields of great scallop, Pecten maximus, larvae in a commercial flow-through rearing system in Norway. Aquaculture International 14: 377-394.

10. Andersen S, Christophersen G, Magnesen, T (2011) Spat production of the great scallop (Pecten maximus): a roller coaster. Canadian Journal of Zoology 89: 585-598

11. Nicolas JL, Corre S, Gauthier G, Robert R, Ansquer D (1996) Bacteria problems associated with scallop Pecten maximus larval culture. Diseases of Aquatic Organisms 27: 67-76.

12. Torkildsen L, Lambert C, Magnesen T, Nylund A, Bergh $\varnothing$ (2005) Bacteria associated with early life stages of the great scallop, Pecten maximus: impact on larval survival. Aquaculture International 13: 575-592.

13. Torkildsen L, Magnesen T (2004) Hatchery production of scallop larvae (Pecten maximus)-survival in different rearing systems. Aquaculture International 12 : 489-507

14. Valiela I (1984) Marine Ecological Processes. Springer-Verlag, New York: 273311

15. Alldredge AL, Passow U, Haddock SHD (1998) The characteristics and transparent exopolymer particle (TEP) content of marine snow formed from thecate dinoflagellates. Journal of Plankton Research 20: 393-406.

16. Turley C (2002) The importance of 'marine snow'. Microbiology Today 29: 177179

17. Diercks A-R, Asper VL (1997) In situ settling speeds of marine snow aggregates below the mixed layer: Black sea and Gulf of Mexico. Deep-Sea Research Part I: Oceanographic Research Papers 44: 385-398.

18. Urakawa H, Kita-Tsukamoto K, Ohwada K (1999) 16 S rDNA restriction fragment length polymorphism analysis of psychrotrophic vibrios from Japanese coastal water. Can J Microbiol 45: 1001-1007.

19. Lyon WJ (2001) TaqMan PCR for detection of Vibrio cholerae 01, O139, Non-O1, and Non-0139 in pure cultures, raw oysters, and synthetic seawater. Appl Environ Microbiol 67: 4685-4693.

20. Gram L, Grossart HP, Schlingloff A, Kiørboe T (2002) Possible quorum sensing in marine snow bacteria: production of acylated homoserine lactones by Roseobacter strains isolated from marine snow. Applied and Environmental Microbiology 68: 4111-4116.

21. De Vittor C, Larato C, Umani SF (2009) The application of a plug-flow reactor to measure the biodegradable dissolved organic carbon (BDOC) in seawater. Bioresour Technol 100: 5721-5728.

22. Fenchel TM, Jørgensen, BB (1977) Detritus food chains of aquatic ecosystems. In: Alexander M (eds) The Role of Bacteria. Advances in Microbial Ecology, Plenum Press, New York 1: 1-58.

23. Abasolo-Pacheco F, Mazón-Suástegui JM, Saucedo PE (2009) Response and condition of larvae of the scallops Nodipecten subnodosus and Argopecten ventricosus reared at the hatchery with different seawater sources. Aquaculture 296: 255-262.

24. Salvesen I, Skjermo J Vadstein O (1999) Growth of turbot (Scophthalmus maximus L.) during first feeding in relation to the proportion of $r / \mathrm{K}$-strategists in the bacterial community of the rearing water. Aquaculture 175: 337-350.

25. Lekang O-I, Kleppe H (2000) Efficiency of nitrification in trickling filters using different filter media. Aquacultural Engineering 21: 181-199.

26. Dhert P, Rombaut G, Suantika G, Sorgeloos P (2001) Advancement of rotifer culture and manipulation techniques in Europe. Aquaculture 200: 129-146.

27. Davidson J, Helwig N, Summerfelt ST (2008) Fluidized sand biofilters used to remove ammonia, biochemical oxygen demand, total coliform bacteria, and suspended solids from an intensive aquaculture effluent. Aquacultural Engineering 39: 6-15.

28. Franco-Nava MA, Blancheton JP, Deviller G, Charrier A, Le-Gall JY (2004) Effect of fish size and hydraulic regime on particulate organic matter dynamics in a recirculating aquaculture system: elemental carbon and nitrogen approach. Aquaculture 239: 179-198.

29. Bergheim A, Brinker A (2003) Effluent treatment for flow through systems and European environmental regulations. Aquacultural Engineering 27: 61-77.

30. Sharrer MJ, Tal Y, Ferrier D, Hankins JA, Summerfelt ST (2007) Membrane biological reactor treatment of a saline backwash flow from a recirculating aquaculture system. Aquacultural Engineering 36: 159-176.

31. Borges M-T, Morais A, Castro PML (2003) Performance of outdoor seawater treatment systems for recirculation in an intensive turbot (Scophthalmus maximus) farm. Aquaculture International 11: 557-570.

32. Brambilla F, Antonini M, Ceccuzzi P, Terova G, Saroglia M (2008) Foam fractionation efficiency in particulate matter and heterotrophic bacteria removal from a recirculating seabass (Dicentrarchus labrax) system. Aquacultural Engineering 39: 37-42.

33. Timmons MB, Ebeling J (2007) Recirculating Aquaculture. NRAC Publication Cayuga Aqua Ventures, New York: 769

34. Marie D, Simon N, Vaulot D (2005) Phytoplankton cell counting by flow cytometry, in Andersen RA (eds.). Algal Culturing Techniques, Elsevier Academic Press, USA: 239-252.

35. Sandaa R-A, Magnesen T, Torkildsen L, Bergh $\varnothing$ (2003) Characterisation of the bacterial community associated with early stages of great scallop (Pecten maximus), using denaturing gradient gel electrophoresis (DGGE). Syst App Microbio 26: 302-311.

36. Sandlund N, Torkildsen L, Magnesen T, Mortensen S, Bergh $\varnothing$ (2006) Immunohistochemistry of great scallop Pecten maximus larvae experimentally challenged with pathogenic bacteria. Dis Aquat Organ 69: 163-173.

37. Laing I (1991) Cultivation of marine unicellular algae. MAFF Laboratory Leaflet No. 67.Directorate of Fisheries Research, Lowestoft, UK: 31.

38. Robert R, Gérard A (1999) Bivalve hatchery techniques: current situation fo the oyster Crassostrea gigas and the scallop Pecten maximus. Aquatic Living Resources 12: 121-130.

39. Torkildsen L, Samuelsen OB, Lunestad BT, Bergh $\varnothing ~(2000)$ Minimum inhibitory concentrations of chloramphenicol, florfenicol, trimethoprim/sulfadiazine and flumequine in seawater of bacteria associated with scallops (Pecten maximus) larvae. Aquaculture 185:1-12

40. Torkildsen L, Coyne R, Samuelsen OB, Magnesen T, Bergh Ø (2002) Treatment of the early life stages of scallop (Pecten maximus) with antimicrobial agents searching for an alternative to chloramphenicol. Aquacult Int 10: 399-409.

41. Jones JB (2006) Why won't they grow? - Inhibitory substances and mollusc hatcheries. Aquaculture international 14: 395-403.

42. Sainz-Hernández JC, Maeda-Martínez AN (2005) Sources of Vibrio bacteria in mollusc hatcheries and control methods: a case study. Aquaculture Research 36: 1611-1618.

43. Alverez-Lajonchére L, Pérez-Roa R (2012) Site selection for tropical marine fish hatchery and its application in the Caribbean coast of Nicaragua. Aquacultura Engineering 46: 10-17.

44. Manahan DT (1990) Adaptations by Invertebrate Larvae for Nutrient Acquisition from Seawater. Amer Zool 30: 147-160.

45. Wakeham SG, Pease TK, Benner R (2003) Hydroxy fatty acids in marine dissolved organic matter as indicators of bacterial membrane material. Organic Geochemistry 34: 857-868.

46. Samain JF, Cochard JC, Chevolot L, Daniel JY, Jeanthon C, et al. (1987) Effet de la qualité de l'eau sur la croissance larvaire de Pecten maximus en écloserie: observations préliminaires. Haliotis 16: 363-381.

47. Peltzer ET, Hayward NA (1996) Spatial and temporal variability of total organic carbon along $140^{\circ} \mathrm{W}$ in the Equatorial Pacific Ocean in 1992. Deep-Sea Research II: Topical Studies in Oceanography 43: 1155-1180.

48. Chopin-Montegut G, Avril B (1993) Vertical distribution and temporal variation of dissolved organic carbon in the North-Western Mediterranean Sea. DeepSea Res 40: 1963-1972.

49. Aluwihare LI, Repeta DJ, Chen RF (1997) A major biopolymeric component to dissolved organic carbon in surface sea water. Nature 387:166-168.

50. Børsheim KY, Myklestad SM, Sneli J-A (1999) Monthly profiles of DOC, mono- 
Citation: Magnesen T, Jacobsen A, Moepi MH (2013) Effect of Different Filter Methods on Seawater Quality at a Marine Scallop Hatchery. J Aquac Res Development 4:168 doi:10.4172/2155-9546.1000168

Page 8 of 8

and polysaccharides at two locations in the Trondheimsfjord (Norway) during two years. Marine Chemistry 63: 255-272

51. Chrzanowski TH, Stevenson LH, Spurrier JD (1983) Transport of dissolved organic carbon through a major creek of the north inlet ecosystem. Mar Ecol Prog Ser 13: 167-174.

52. Adams DD, Richard FA (1968) Dissolved organic matter in an anoxic fjord, with special reference to the presence of mercaptans. Deep-Sea Res 15: 479-481.

53. Heip CHR, Goosen NK, Herman PMJ, Kromkamp J, Middelburg JJ, et al (1995) Production and consumption of biological particles in temperate tidal estuaries. Oceanogr Mar Biol Ann Rev 33: 1-149.

54. Garneau M-Ė, Vincent WF, Terrado R, Lovejoy C (2009) Importance of particleassociated bacterial heterotrophy in a coastal Arctic ecosystem. Journal of Marine Systems 75: 185-197.

55. Cole JJ, Likens GE, Strayer DL (1982) Photosynthetically produced dissolved organic carbon: An important carbon source for planktonic bacteria. Limnology and Oceanography 27: 1080-1090.

56. Skjermo J, Salvesen I, Øie G, Olsen Y, Vadstein O (1997) Microbially matured seawater: a technique for selection of a non-opportunistic bacterial flora in seawater that may improve performance of marine larvae. Aquaculture International 5: 13-28.

57. Park J, Kim Y, Kim P-K, Daniels HV (2011) Effects of two different ozone doses on seawater recirculating systems for black sea bream Acanthopagrus schlegeli (Bleeker): Removal of solids and bacteria by foam fractionation. Aquacultural Engineering 44: 19-24.

58. Jacobsen A, Egge JK, Heimdal BR (1995) Effects of increased concentration of nitrate and phosphate during a springbloom experiment in mesocosm. Journal of Experimental Marine Biology and Ecology 187: 239-251.

59. D'orbcastel ER, Blancheton J-P, Belaud A (2009) Water quality and rainbow trout performance in a Danish Model Farm recirculating system: Comparison with a flow through system. Aquacultural Engineering 40: 135-143.

60. Leonard N, Blancheton JP, Guiraud JP (2000) Populations of heterotrophic bacteria in an experimental recirculating aquaculture system Aquacultural Engineering 22: 109-120.

61. Austin B (1988) Marine Microbiology, (1stedn). Cambridge University Press, New York, USA.
62. Jorquera MA, Lody M, Leyton Y, Riquelme C (2004) Bacteria of subclass $\mathrm{Y}$-Proteobacteria associated with commercial Argopecten purpuratus (Lamark 1819) hatcheries in Chile. Aquaculture 236: 37-51.

63. Yamamoto S, Shinoda S, Kawaguchi M, Wakamatsu K, Makita M (1983) Polyamine distribution in Vibrionaceae: norspermidine as a general constituent of Vibrio species. Can J Microbiol 29: 724-728.

64. Attamadal KJK, Salvesen I, Xue R, Øie G, Størseth TR, et al. (2012) Recirculation as a possible microbial control strategy in the production of marine larvae. Aquacultural Engineering 46: 27-39.

65. Lewis EJ, Farley CA, Baya A Navarro R (1996) Juvenile oyster disease (JOD) transmission and bacteriological studies. 16th Ann Meet, Milford Aquaculture Seminar, Milford, Connecticut. Journal of Shellfish Research 15: 457.

66. Nottage AS, Sinclair PD, Birkbeck TH (1989) The role of low molecular ciliostatic toxins in Vibriosis of bivalve mollusks. J Aquat Anim Health 1:180-186.

67. Brunvold L, Sandaa RA, Mikkelsen H, Welde E, Bleie H, et al. (2007) Characterisation of bacterial communities associated with early stages of intensively reared cod (Gadus morhua) using denaturing gradient gel electrophoresis (DGGE). Aquaculture 272: 319-327.

68. Vasconcelos M, Leala MF, Van den Berg MG (2002) Influence of the nature of the exudates released by different marine algae on the growth, trace metal uptake and exudation of Emiliania huxleyi in natural seawater. Marine Chemistry 77 : 187-210.

69. Salvesen I, Reitan KI, Skjermo J, Øie G (2000) Microbial environments in marine larviculture:Impacts of algal growth rates on the bacterial load in six microalgae. Aquaculture International 8: 275-287.

70. Hattenrath-Lehmann TK, Gobler CJ (2011) Ilelopathic inhibition of competing phytoplankton by North American strains of the toxic dinoflagellate, Alexandrium fundyense: evidence from field experiments, laboratory experiments, and bloom events. Harmful algae 11: 106-116.

71. Fistarol GO, Legrand C, Selander E, Hummert C, Stolte W, et al. (2004) Allelopathy in Alexandrium spp.: effect on a natural plankton community and on algal monocultures. Aquatic Microbial Ecology 35: 45-56.

72. Vidoudez C, Nejstgaard JC, Jakobsen HH, Pohnert G (2011) Dynamics of dissolved and particulate polyunsaturated aldehydes in mesocosms inoculated with different densities of the diatom Skeletonema marinoi. Marine Drugs 9: 345-358. 